\title{
Influence of hafnium oxide on the structure and properties of powders and ceramics of the YSZ- $\mathrm{HfO}_{2}$ composition
}

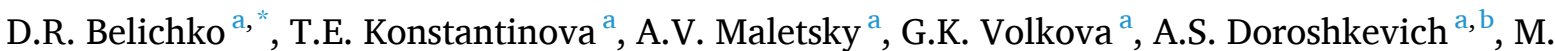 \\ V. Lakusta ${ }^{a}$, M. Kulik ${ }^{\mathrm{c}}$, A.A. Tatarinova ${ }^{\mathrm{b}}$, D. Mardare ${ }^{\mathrm{d}}$, C. Mita ${ }^{\mathrm{e}}$, N. Cornei ${ }^{\mathrm{e}}$ \\ ${ }^{\text {a }}$ Donetsk Institute for Physics and Engineering Named After O.O. Galkin, Donetsk, Ukraine \\ b Joint Institute for Nuclear Research, str. Joliot-Curie, 6, Dubna, 141980, Russia \\ ${ }^{\mathrm{c}}$ Institute of Physics, Maria Curie-Skłodowska University, Pl. Marii Curie-Sklodowskiej 1, 20-031, Lublin, Poland \\ ${ }^{\mathrm{d}}$ Alexandru Ioan Cuza University of Iasi, Faculty of Physics, Romania \\ ${ }^{\mathrm{e}}$ Alexandru Ioan Cuza University of Iasi, Faculty of Chemistry, Romania
}

\section{A R T I C L E I N F O}

\section{Keywords:}

Zirconium dioxide

Hafnium oxide

Nanopowders

Ceramics

Mechanical properties

Structure

\begin{abstract}
A B S T R A C T
Using the X-ray diffraction, internal friction, 4-point bending, and electron microscopy methods we have studied the structural compatibility and influence of $\mathrm{Y}_{2} \mathrm{O}_{3}$ and $\mathrm{HfO}_{2}$ dopants addition on the structure and phase composition of $\mathrm{ZrO}_{2}$ powders and ceramics based on them. The mechanical properties of $\mathrm{ZrO}_{2}-\mathrm{Y}_{2} \mathrm{O}_{3}-\mathrm{HfO}_{2}(\mathrm{YSZ})$ system have been investigated.

It was determined that the similarity of the structure and properties of yttrium and hafnium oxides is not complete. The individual structural features of $\mathrm{ZrO}_{2}, \mathrm{Y}_{2} \mathrm{O}_{3}$, and $\mathrm{HfO}_{2}$ oxides reviled themselves during the formation of ternary systems of the YSZ-Hf type. Studies of the $\mathrm{nY}_{2} \mathrm{O}_{3}-\mathrm{ZrO}_{2}-\mathrm{mHf}_{2} \mathrm{O}_{3}$ system in the range of hafnium amount from 1 to $15 \mathrm{wt} \%$ and yttrium oxide concentration from 0 to $12 \mathrm{~mol} \%$ showed the possibility of increase in the values of physical and mechanical properties of common two-component zirconium ceramics by the forming ternary systems of the YSZ-Hf type.
\end{abstract}

\section{Introduction}

Nowadays ceramic materials are widely used in the engineering, industry and medicine [1,2] due to the high level of their mechanical properties, in particular, wear resistance and hardness. In the series of oxide ceramics, a special place is occupied by materials based on zirconium dioxide $\left(\mathrm{ZrO}_{2}\right) . \mathrm{ZrO}_{2}$-based ceramics are distinguished by the presence of ionic conductivity at temperatures above $600{ }^{\circ} \mathrm{C}[3,4]$, biocompatibility, high wear resistance [5,6], chemical, thermal [7] and radiation resistance [8]. Zirconia ceramics are also indispensable in mechanical engineering for the manufacturing of parts of mechanisms operating under high mechanical loads, in chemically aggressive environments; it is used in medicine, as transplants [9] and for energy producing (structural elements of SOFC, nuclear reactors [10]), etc.

The development of the novel technologies requires continuous improvement of the technical and functional characteristics of ceramics. The main part of zirconia based ceramics of industrial importance is binary solid solutions of $\mathrm{ZrO}_{2}-\mathrm{Y}_{2} \mathrm{O}_{3}$ or $\mathrm{ZrO}_{2}-\mathrm{MgO}$ type. Doping with the third component is a promising way to obtain new properties of ceramics based on zirconium dioxide along with the physical modification of the microstructure during technological processes. To date, the issues about obtaining metal oxide ceramics based on $\mathrm{ZrO}_{2}$ have been rather widely studied in the papers $[11,12]$. Nevertheless, ternary oxide systems, in particular, having hafnium in their composition, have not been sufficiently studied. Thus, they undoubtedly arouse a scientific interest. The aim of this work is to study of the effect of hafnium oxide addition on the structure and properties of yttrium-stabilized zirconia nanopowders and to investigate hafnium oxide powders and ceramics based on them.

\section{Materials and methods}

In the present study, we have used hafnium oxide powders stabilized by the different amounts of yttrium oxide: $\mathrm{nY}_{2} \mathrm{O}_{3}+\mathrm{HfO}_{2}$, where $\mathrm{n}=0$, $3,6,8,12 \%$ mol. (system: $\mathrm{nY}_{2} \mathrm{O}_{3}-\mathrm{HfO}_{2}$ ), as well as zirconium oxide powders stabilized with yttrium oxide and additionally doped with hafnium oxide $3 \%$ mol. $\mathrm{Y}_{2} \mathrm{O}_{3}+\mathrm{ZrO}_{2}+\mathrm{mHfO}_{2}$, where $\mathrm{m}=1,5,10,15 \%$ wt (system: $3 \mathrm{YSZ}-\mathrm{mHfO}_{2}$ ). Powder materials were prepared by co-

\footnotetext{
* Corresponding author. Donetsk Institute for Physics and Engineering Named After O.O.Galkin, Kiev, Ukraine

E-mail addresses: danil.belichko@yandex.ru (D.R. Belichko), doroh@jinr.ru (A.S. Doroshkevich), mkulik@hektor.umcs.lublin.pl (M. Kulik).
} 
precipitation from salts at room temperature. Zirconium oxide powders were calcined at $\mathrm{T}=1000{ }^{\circ} \mathrm{C}$, hafnium oxide powders at $\mathrm{T}=1000^{\circ}$, $1200^{\circ}, 1400^{\circ} \mathrm{C}$ in air for $2 \mathrm{~h}$. Ceramic samples were obtained by uniaxial molding of powders in steel molds, followed by processing under conditions of high hydrostatic pressure $(\mathrm{HHP})=400 \mathrm{MPa}$ and sintered at $\mathrm{T}$ $=1500{ }^{\circ} \mathrm{C}$ in the air for $1 \mathrm{~h}$

The structure and mechanical properties of powders based on zirconia and hafnium oxide and their ceramics have been studied. The method of the X-ray structural analysis (XSA) was used to study the phase composition of the initial powders and ceramics based on them. Using the Rietveld method [13], the lattice parameters, the degree of tetragonality and the unit cell volume were calculated; the values of coherent X-ray scattering (CSR) regions were estimated.

The values of the normal elastic modulus (Young's modulus, E) were measured by the Compound Piezoelectric Vibrator Method (Internal Friction Method) using technology described in work [14]. Strength was measured on the Tinius Olsen H50KT setup using the 4-point bending method [15]. The fracture surface structure was investigated using the JEOL JSM 6510lv scanning electron microscope.

Errors measurements were determined by the standard deviation method. The errors of calculating the unit cell parameters were carried out according to paper [13].

\section{Research results and discussion}

\subsection{Structural compatibility of $\mathrm{HfO}_{2}$ and $\mathrm{Y}_{2} \mathrm{O}_{3}$ oxides}

Hafnium oxide is considered to be a structural analog of zirconium dioxide, which makes it possible to use it as an alloying element in zirconium ceramics in order to modify its properties. In the study [16], it is shown that yttrium oxide acts as stabilizer of high-temperature phases of hafnium and zirconium oxides. Due to the different valences of Hf4 + and $\mathrm{Y} 3+$, an oxygen vacancy is created which stabilize the high-temperature hafnium phases.

Zirconium and hafnium oxides exist in three crystallographic modifications: monoclinic (M), tetragonal (T), cubic (C), and are characterized by close lattice parameters. They have the same ionic radii $\left(\mathrm{Zr}^{4+}=\right.$ $\mathrm{Hf}^{4+}=0.82 \AA$ with a coordination number of 8) and at the same time they accompany each other in nature. Hafnium oxide has a higher density $\left(\mathrm{M} \mathrm{HfO}_{2}=9.68 \mathrm{~g} / \mathrm{cm}^{3}\right.$, $\mathrm{T} \mathrm{HfO}{ }_{2}=10.01 \mathrm{~g} / \mathrm{cm}^{3}, \mathrm{C} \mathrm{HfO}_{2}=10.43$ $\mathrm{g} / \mathrm{cm}^{3}$ ) [17], as well as a higher hardness compared to zirconium oxide $\left(\mathrm{M} \mathrm{ZrO}_{2}=5.85 \mathrm{~g} / \mathrm{cm}^{3}, \mathrm{~T} \mathrm{ZrO}_{2}=6.02 \mathrm{~g} / \mathrm{cm}^{3}, \mathrm{C} \mathrm{ZrO}_{2}=5.92 \mathrm{~g} / \mathrm{cm}^{3}\right)$.

\section{2. $\mathrm{Y}_{2} \mathrm{O}_{3}-\mathrm{HfO}_{2}$ system. Status chart analysis}

The necessary information relating to the equilibrium of phases, temperatures, and component concentrations is provided by state diagrams. Consider the phase equilibrium diagram of the $\mathrm{Y}_{2} \mathrm{O}_{3}-\mathrm{HfO}_{2}$ system. According to the diagram (Fig. 1), less than $1 \% \mathrm{Y}_{2} \mathrm{O}_{3}$ can dissolve in monoclinic hafnium oxide, in this single-phase state it can be up to $\sim 1800^{\circ} \mathrm{C}$. Tetragonal hafnium oxide in the form of a solid solution with yttrium oxide is stable at $\mathrm{T} \geq 1770{ }^{\circ} \mathrm{C}$ [18]. In the range of $\mathrm{Y}_{2} \mathrm{O}_{3}$ concentrations from $1 \%$ to $5.5 \%$ solid solutions of monoclinic and cubic hafnium oxides coexist in different ratios. Cubic hafnium oxide (a structural type of fluorite, F) exists at yttrium concentration from 5.5\% to $55 \%$. The phase composition of the studied YSZ - $\mathrm{HfO}_{2}$ - powders and CSR values according to X-ray diffraction data are given in Table 1.

\subsection{Analysis of the results of an experimental study of hafnium powders}

The diffraction patterns of $\mathrm{Y}_{2} \mathrm{O}_{3}-\mathrm{HfO}_{2}$ powders annealed at different temperatures of $1000,1200,1400{ }^{\circ} \mathrm{C}$ are shown in Fig. 2.

As can be seen from Table 1 , at $\mathrm{Y}_{2} \mathrm{O}_{3}$ concentration of 3 and $12 \mathrm{~mol} \%$, the powders of $\mathrm{HfO}_{2}-\mathrm{Y}_{2} \mathrm{O}_{3}$ system obtained at all the annealing temperatures are almost single-phased, namely, in the first case, they are monoclinic, in the second, cubic, with a small content of the

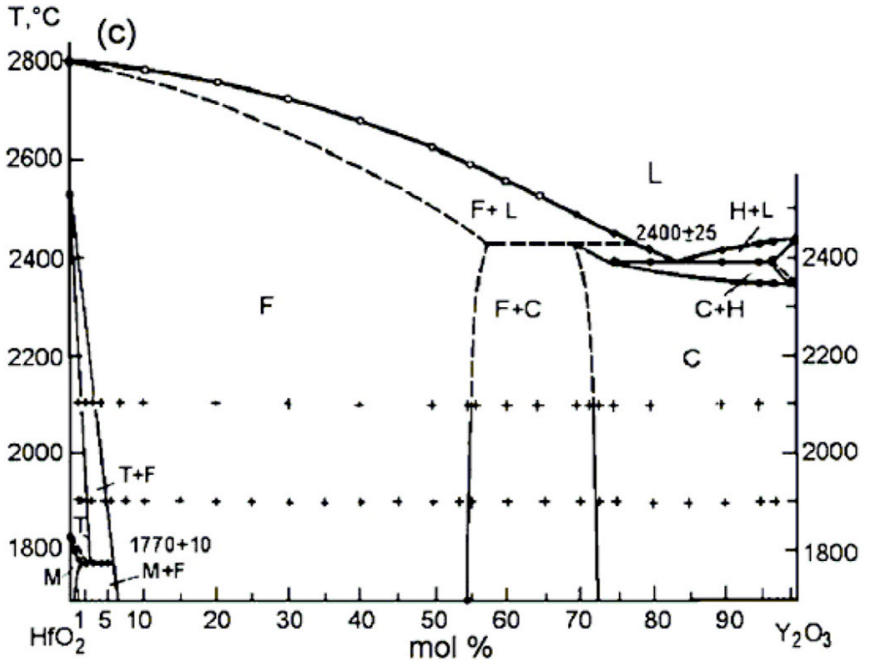

Fig. 1. The phase diagram of the $\mathrm{Y}_{2} \mathrm{O}_{3}-\mathrm{HfO}_{2}$ system [19].

Table 1

The phase composition of the powder system of composition $\mathrm{YSZ}$ - $\mathrm{HfO}_{2}$ and the CSR values of the phases present. Notes: M, C are abbreviation of themonoclinic and cubic hafnium oxide respectively; $\mathrm{D}_{\mathrm{m}}$, Dc are the CSR values of the $\mathrm{M}$ and $\mathrm{C}$ phases.

\begin{tabular}{llll}
\hline Powders & The phase composition, $\%$ & \multicolumn{2}{l}{ CSR value, nm } \\
\hline $\mathrm{HfO}_{2}, 1000^{\circ} \mathrm{C} 2 \mathrm{~h}$ & $100 \% \mathrm{M}$ & $\mathrm{D}_{\mathrm{m}}=20$ & \\
$3 \mathrm{Y}_{2} \mathrm{O}_{3}-\mathrm{HfO}_{2}, 1000^{\circ} \mathrm{C} 2 \mathrm{~h}$ & $98 \% \mathrm{M}+2 \% \mathrm{C}$ & $\mathrm{D}_{\mathrm{m}}=20$ & \\
$3 \mathrm{Y}_{2} \mathrm{O}_{3}-\mathrm{HfO}_{2}, 1200^{\circ} \mathrm{C} 2 \mathrm{~h}$ & $91 \% \mathrm{M}+9 \% \mathrm{C}$ & $\mathrm{D}_{\mathrm{m}}=23$ & \\
$3 \mathrm{Y}_{2} \mathrm{O}_{3}-\mathrm{HfO}_{2}, 1400^{\circ} \mathrm{C} 2 \mathrm{~h}$ & $88 \% \mathrm{M}+12 \% \mathrm{C}$ & $\mathrm{D}_{\mathrm{m}}=55$ & \\
$6 \mathrm{Y}_{2} \mathrm{O}_{3}-\mathrm{HfO}_{2}$, & $52 \% \mathrm{M}+48 \% \mathrm{C}$ & $\mathrm{D}_{\mathrm{m}}=22$ & $\mathrm{Dc}=17.5$ \\
$1000^{\circ} \mathrm{C} 2 \mathrm{~h}$ & & & \\
$6 \mathrm{Y}_{2} \mathrm{O}_{3}-\mathrm{HfO}_{2}, 1200^{\circ} \mathrm{C} 2 \mathrm{~h}$ & $63 \% \mathrm{M}+37 \% \mathrm{C}$ & $\mathrm{D}_{\mathrm{m}}=23$ & $\mathrm{Dc}=32$ \\
$6 \mathrm{Y}_{2} \mathrm{O}_{3}-\mathrm{HfO}_{2}, 1400^{\circ} \mathrm{C} 2 \mathrm{~h}$ & $51 \% \mathrm{M}+49 \% \mathrm{C}$ & $\mathrm{D}_{\mathrm{m}}=92$ & $\mathrm{Dc}=92$ \\
$8 \mathrm{Y}_{2} \mathrm{O}_{3}-\mathrm{HfO}_{2}, 1000^{\circ} \mathrm{C} 2 \mathrm{~h}$ & $23 \% \mathrm{M}+77 \% \mathrm{C}$ & $\mathrm{D}_{\mathrm{m}}=17.8$ & $\mathrm{Dc}=22.7$ \\
$8 \mathrm{Y}_{2} \mathrm{O}_{3}-\mathrm{HfO}_{2}, 1200^{\circ} \mathrm{C} 2 \mathrm{~h}$ & $40 \% \mathrm{M}+60 \% \mathrm{C}$ & $\mathrm{D}_{\mathrm{m}}=26.5$ & $\mathrm{Dc}=31.5$ \\
$8 \mathrm{Y}_{2} \mathrm{O}_{3}-\mathrm{HfO}_{2}, 1400^{\circ} \mathrm{C} 2 \mathrm{~h}$ & $33 \% \mathrm{M}+67 \% \mathrm{C}$ & $\mathrm{D}_{\mathrm{m}}=93$ & $\mathrm{Dc}=94$ \\
$12 \mathrm{Y}_{2} \mathrm{O}_{3}-\mathrm{HfO}_{2}, 1000^{\circ} \mathrm{C} 2 \mathrm{~h}$ & $2 \% \mathrm{M}+98 \% \mathrm{C}$ & & $\mathrm{Dc}=32$ \\
$12 \mathrm{Y}_{2} \mathrm{O}_{3}-\mathrm{HfO}_{2}, 1200^{\circ} \mathrm{C} 2 \mathrm{~h}$ & $5 \% \mathrm{M}+95 \% \mathrm{C}$ & & $\mathrm{Dc}=38$ \\
$12 \mathrm{Y}_{2} \mathrm{O}_{3}-\mathrm{HfO}_{2}, 1400^{\circ} \mathrm{C} 2 \mathrm{~h}$ & $0 \% \mathrm{M}+100 \% \mathrm{C}$ & & $\mathrm{D}_{\mathrm{k}}=97$ \\
\hline
\end{tabular}

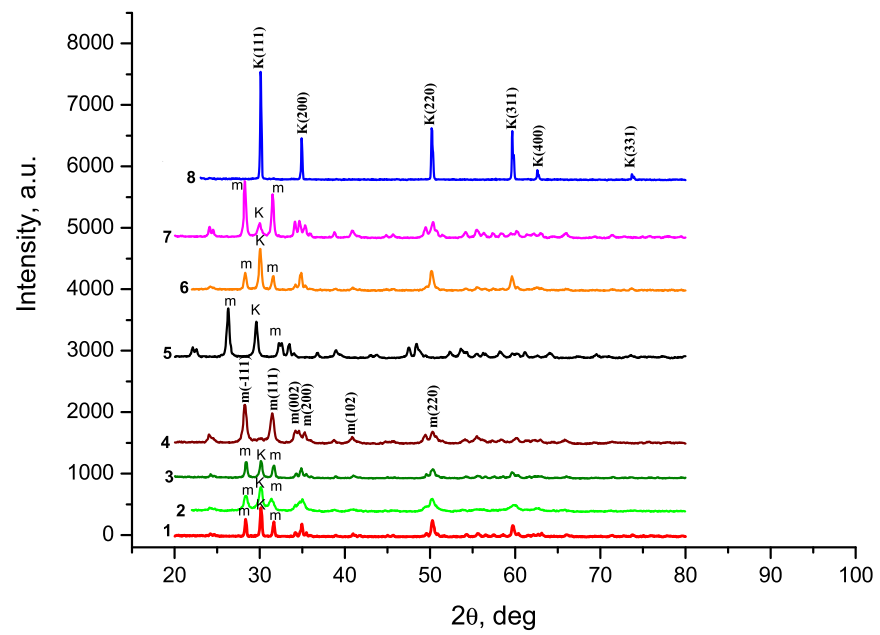

Fig. 2. Diffraction patterns of the system $\mathrm{Y}_{2} \mathrm{O}_{3}-\mathrm{HfO}_{2}$ - powders annealed at temperatures: $1000,1200,1400{ }^{\circ} \mathrm{C}$, where $1-6 \mathrm{Y}_{2} \mathrm{O}_{3}-\mathrm{HfO}_{2}, 1400{ }^{\circ} \mathrm{C} ; 2$ $6 \mathrm{Y}_{2} \mathrm{O}_{3}-\mathrm{HfO}_{2}, 1000{ }^{\circ} \mathrm{C} ; 3-6 \mathrm{Y}_{2} \mathrm{O}_{3}-\mathrm{HfO}_{2}, 1200{ }^{\circ} \mathrm{C} ; 4-3 \mathrm{Y}_{2} \mathrm{O}_{3}, 1000{ }^{\circ} \mathrm{C} ; 5-\mathrm{HfO}_{2}$, $1000{ }^{\circ} \mathrm{C} ; 6-8 \mathrm{Y}_{2} \mathrm{O}_{3}-\mathrm{HfO}_{2}, 1200{ }^{\circ} \mathrm{C} ; 7-3 \mathrm{Y}_{2} \mathrm{O}_{3}-\mathrm{HfO}_{2}, 1200{ }^{\circ} \mathrm{C} ; 8-12 \mathrm{Y}_{2} \mathrm{O}_{3}-\mathrm{HfO}_{2}$, $1400{ }^{\circ} \mathrm{C}$. 
accompanying phase.

At the concentration of $\mathrm{Y}_{2} \mathrm{O}_{3} 6$ and $8 \%$ mol., the amount of hafnium fluorite in the two-phase powder system is less than $50 \% \mathrm{~mol}$. (at $6 \%$ mol. $\mathrm{Y}_{2} \mathrm{O}_{3}$ ) and more than $60 \% \mathrm{~mol}$. (at $8 \%$ mol. $\mathrm{Y}_{2} \mathrm{O}_{3}$ ), which does not correspond to the $\mathrm{HfO}_{2}-\mathrm{Y}_{2} \mathrm{O}_{3}$ phase diagram according to which, at $8 \%$ mol. $\mathrm{Y}_{2} \mathrm{O}_{3}$, the composition should contain $100 \%$ fluorite. However, there is no contradiction here, since state diagrams describe the coexistence of phases in equilibrium at a given temperature. Nanopowder systems are far from equilibrium due to excess of free energy, therefore, in this powder system, single-phase hafnium fluorite is observed only at $1400{ }^{\circ} \mathrm{C}$ and the composition of $\mathrm{HfO}_{2}-12 \%$ mol. $\mathrm{Y}_{2} \mathrm{O}_{3}$.

The CSR value is a structurally sensitive characteristic of powders, as such an important characteristic as the rigidity of particle aggregates (agglomerates), therefore, in the studied powders the CSR sizes in the monoclinic and cubic phases were calculated. As can be seen from Table 1, the CSR value increases with an increase in the annealing temperature for both considered polymorphic structural modifications.

The effect of changes in yttrium concentration on the CSR value in these polymorphic modifications at low $\left(1000{ }^{\circ} \mathrm{C}\right.$ and $\left.1200{ }^{\circ} \mathrm{C}\right)$ temperatures was not revealed. However, at $1400{ }^{\circ} \mathrm{C}$ there is a sharp increase in the CSR size with an increase in the concentration of yttrium oxide for both polymorphic modifications. This tendency is especially explicit for the monoclinic phase. Thus, the CSR values in monoclinic hafnium oxide for compositions with $3 \mathrm{~mol} \%, 6 \mathrm{~mol} \%$. and $8 \mathrm{~mol} \% \mathrm{Y}_{2} \mathrm{O}_{3}$ at $1400{ }^{\circ} \mathrm{C}$ with an increase in the concentration of $\mathrm{Y}_{2} \mathrm{O}_{3}$ increased by about 2 times and amounted to $\mathrm{D}_{\mathrm{m}}=55,92,93 \mathrm{~nm}$, respectively. In a 1400-degree calcined powder, the CSR values in cubic and monoclinic $\mathrm{HfO}_{2}$ are the same at all $\mathrm{Y}_{2} \mathrm{O}_{3}$ concentrations. Comparing the CSR value in both phases at low temperatures and at $1400{ }^{\circ} \mathrm{C}$, we can see that their value increased approximately in 4 times. This indicates that temperatures of $1000{ }^{\circ} \mathrm{C}$ and $1200{ }^{\circ} \mathrm{C}$ for hafnium oxide are low and the processes of coalescence and recrystallization of particles are inhibited. In 1400 - degree calcined powders, these processes are very active and the CSR values reach the limit of nanoscale $(100 \mathrm{~nm})$.

The results of calculating the lattice parameters $\left(a_{k}\right)$ and the unit cell volume $\left(V_{k}\right)$ of hafnium fluorite are given in Table $1 \mathrm{a}$.

The lattice parameters of hafnium oxide were calculated only in 1400-degree annealed powders since their crystal lattice is more perfect in comparison to the low-temperature forms. In this powders the error in calculating of the parameters is beyond the permissible error (an order of magnitude higher). For the same reason, it is not possible to reliably calculate the lattice parameter of the cubic phase in a 1400-degree calcined powder of the composition $3 \mathrm{Y}_{2} \mathrm{O}_{3}-\mathrm{HfO}_{2}$ (due to the small amount of the latter).

As can be seen from Table $1 \mathrm{a}$, at the concentrations of $\mathrm{Y}_{2} \mathrm{O}_{3}$ of 6 and $8 \mathrm{~mol} \%$. the lattice parameter and the cell volume of hafnium fluorite have the same values $a_{k}=5.1241 \AA$ and $V_{k}=139.59 \AA^{3}$, respectively. A marked increase in the indicated parameters is observed only at an additive concentration of $\mathrm{Y}_{2} \mathrm{O}_{3} \mathrm{n}=12 \%: a_{\kappa}=5.1271 \AA, V_{k}=134.77 \AA^{3}$.

According to the Vegard rule an increase in the lattice parameter in solid solutions [20] occurs if and only if the ionic radius of the impurity is larger than the ionic radius of the matrix. As can be seen, this condition is satisfied: $\mathrm{r}\left(\mathrm{Y}^{3+}\right)=0.97 \AA, \mathrm{r}\left(\mathrm{Hf}^{4+}\right)=0.82 \AA$ (for c.h. = 8); therefore, cubic hafnium oxide is a substitutional solid solution.

Table 1a

Lattice parameters and unit cell volumes of cubic hafnium oxide powders annealed at $1400^{\circ} \mathrm{C}, 2 \mathrm{~h}$.

\begin{tabular}{lll}
\hline Powder composition & Parameter $a_{\kappa}, \AA$ & Cell volume, $\AA^{3}$ \\
\hline $6 \mathrm{Y}_{2} \mathrm{O}_{3}-\mathrm{HfO}_{2}$ & $5.1241 \pm 0.0002$ & 134.59 \\
$8 \mathrm{Y}_{2} \mathrm{O}_{3}-\mathrm{HfO}_{2}$ & $5.1241 \pm 0.0002$ & 134.59 \\
$12 \mathrm{Y}_{2} \mathrm{O}_{3}-\mathrm{HfO}_{2}$ & $5.1271 \pm 0.0002$ & 134.77 \\
\hline
\end{tabular}

\subsection{Analysis of the results of an experimental study of hafnium ceramics}

The diffraction patterns of the ceramics of the compositions $\mathrm{HfO}_{2}$ and $3 \mathrm{Y}_{2} \mathrm{O}_{3}-\mathrm{HfO}_{2}$ obtained at $\mathrm{T}=1500^{\circ} \mathrm{C}$ are shown in Fig. 3 .

The phase composition of these ceramics is given in Table 1b. For comparison, the phase composition of the initial powders is given.

As can be seen from Table $1 \mathrm{~b}$, the phase composition of ceramics is slightly different from the phase composition of the initial powders, i.e. the proportion of phase transformations is negligible.

The measured mechanical characteristics of $\mathrm{nY}_{2} \mathrm{O}_{3}-\mathrm{HfO}_{2}$ ceramics $(\mathrm{n}=0,3,6)$ are shown in Table 2.

As can be seen from Table 2, the highest density value was shown in ceramics with the monoclinic lattice of hafnium oxide of the compositions $\mathrm{HfO}_{2}$ and $3 \mathrm{Y}_{2} \mathrm{O}_{3}-\mathrm{HfO}_{2}$ ( 9.65 and $9.85 \mathrm{~g} / \mathrm{cm}^{3}$, respectively), which in both cases is $99.7 \%$ of the theoretical limit. The same ceramics have the highest hardness (1165 and $1130 \mathrm{HV}$, respectively) with a low level of porosity ( 0.31 and $0.3 \%$, respectively). The low mechanical properties were observed in two-phase ceramics with the composition $6 \mathrm{Y}_{2} \mathrm{O}_{3}-\mathrm{HfO}_{2}$, in which the ratio of monoclinic and cubic hafnium oxide was 1: 1 .

\subsection{System $3 \mathrm{YSZ}_{-}-\mathrm{HfO}_{2}$, structure}

3.1.1. Powders. The results of studying the phase composition of the $3 \mathrm{~mol} . \% \mathrm{Y}_{2} \mathrm{O}_{3}+\mathrm{ZrO}_{2}+\mathrm{mHfO}_{2}$ powder system, where $\mathrm{m}=1,5,10,15$ $\mathrm{wt} \%$, and the parameters of its fine structure are given in Table 3.

According to Table 3, in the two-phase $(\mathrm{M}+\mathrm{T}) 3 \mathrm{YSZ}^{-\mathrm{HfO}_{2}}$ system (powders), with an increase in the concentration of hafnium oxide, an increase in the amount of monoclinic phase is observed (Fig. 4).

As can be seen from Fig. 4, at low concentrations of the $\mathrm{HfO}_{2}$ additive (1-5\%), the amount of the monoclinic phase is minimal $(\sim 1 \%)$, and at large (10 and $15 \mathrm{~mol} \%$ ) it increases by an order of magnitude (up to $11 \%)$. An increase in the amount of the monoclinic phase in the studied solid solution of zirconium oxide can be explained by the nonvalence of $\mathrm{Hf}$ to $\mathrm{Zr}$. Since the addition of $\mathrm{HfO}_{2}$ does not create oxygen vacancies in an amount sufficient to stabilize the tetragonal phase. As a result, the amount of $\mathrm{M}$ - phase increases with increasing concentrations of hafnium oxide additive. As can be concluded from Table 3, with an increase in the $\mathrm{HfO}_{2}$ concentration, the lattice parameters a and c of tetragonal zirconium dioxide change: the parameter a decreases and the parameter c increases. With the small amount addition of $\mathrm{HfO}_{2}$, changes in the lattice parameters of the latter (according to the Vegard rule) do not occur, because their ionic radii are the same $\mathrm{Zr}^{4+}=\mathrm{Hf}^{4+}=0.82 \AA$ (c.

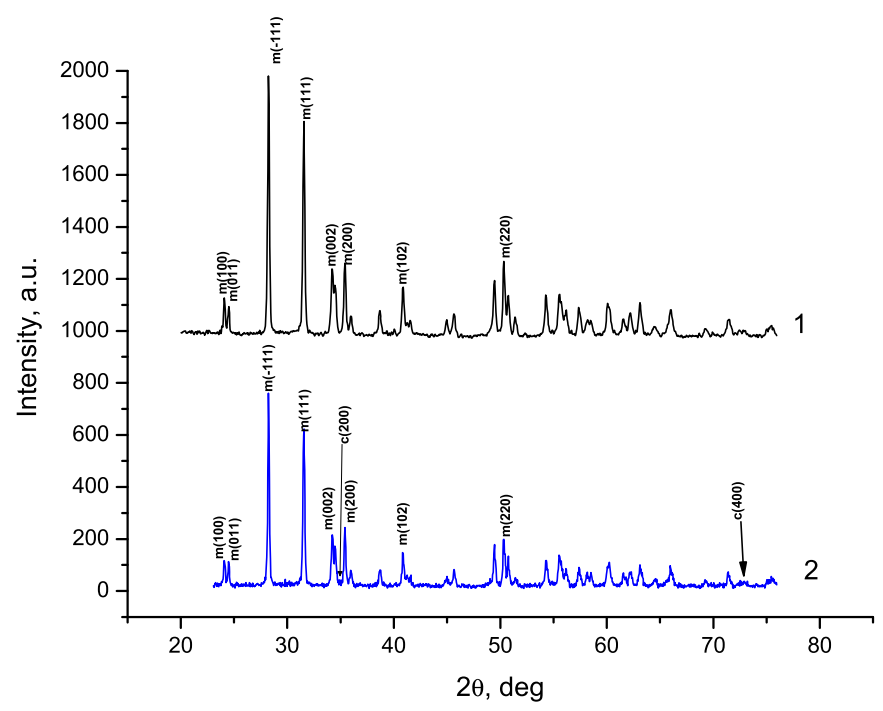

Fig. 3. Diffraction patterns of ceramics of the compositions $\mathrm{HfO}_{2}$ and $3 \mathrm{Y}_{2} \mathrm{O}_{3}-\mathrm{HfO}_{2}$, where (1) $\mathrm{HfO}_{2}$, (2) $3 \mathrm{Y}_{2} \mathrm{O}_{3}-\mathrm{HfO}_{2}$. 
Table 1b

The phase composition of hafnium ceramics, at a sintering temperature of 1500 ${ }^{\circ} \mathrm{C}, 1 \mathrm{~h}$.

\begin{tabular}{|c|c|c|c|c|}
\hline $\begin{array}{l}\text { The composition of } \\
\text { ceramics }\end{array}$ & $\mathrm{HfO}_{2}$ & $3 \mathrm{Y}_{2} \mathrm{O}_{3}-\mathrm{HfO}_{2}$ & $6 \mathrm{Y}_{2} \mathrm{O}_{3}-\mathrm{HfO}_{2}$ & $12 \mathrm{Y}_{2} \mathrm{O}_{3}-\mathrm{HfO}_{2}$ \\
\hline $\begin{array}{c}\text { Ceramic phase } \\
\text { composition }\end{array}$ & $\begin{array}{l}100 \% \mathrm{M} \\
\mathrm{HfO}_{2}\end{array}$ & $\begin{array}{l}90 \% \mathrm{M}+10 \% \\
\mathrm{C}\end{array}$ & $\begin{array}{l}50 \% \mathrm{M}+50 \% \\
\mathrm{C}\end{array}$ & $100 \%{\mathrm{C} \mathrm{HfO}_{2}}_{2}$ \\
\hline $\begin{array}{l}\text { The phase } \\
\text { composition of the } \\
\text { powders }\end{array}$ & $\begin{array}{l}100 \% \mathrm{M} \\
\mathrm{HfO}_{2}\end{array}$ & $98 \% \mathrm{M}+2 \% \mathrm{C}$ & $\begin{array}{l}52 \% M+48 \% \\
C\end{array}$ & $2 \% \mathrm{M}+98 \% \mathrm{C}$ \\
\hline
\end{tabular}

Table 2

The mechanical characteristics of the ceramics of the $\mathrm{Y}_{2} \mathrm{O}_{3}-\mathrm{HfO}_{2}$ system.

\begin{tabular}{llll}
\hline Characteristics of ceramics & $\mathrm{HfO}_{2}$ & $3 \mathrm{Y}_{2} \mathrm{O}_{3}-\mathrm{HfO}_{2}$ & $6 \mathrm{Y}_{2} \mathrm{O}_{3}-\mathrm{HfO}_{2}$ \\
\hline$\rho, \mathrm{g} / \mathrm{cm}^{3}$ & $9,65 \pm 0.04$ & $9,85 \pm 0.04$ & $8,1 \pm 0.03$ \\
$\rho_{\text {theor }}, \mathrm{g} / \mathrm{cm}^{3}$ & 9,68 & 9,88 & 10,06 \\
$\mathrm{HV}$ & 1165 & 1130 & 1040 \\
$\varepsilon, \%$ & 0,31 & 0,3 & 24 \\
\hline
\end{tabular}

Note: $\rho$ is the density of samples, HV is Vickers hardness, $\varepsilon$ is porosity.

Table 3

The phase composition and fine structure parameters of $3 \mathrm{YSZ}+\mathrm{mHfO}_{2}$ annealed at $1000^{\circ} \mathrm{C}, 2 \mathrm{~h}$.

\begin{tabular}{|c|c|c|c|c|c|c|}
\hline \multirow{2}{*}{$\begin{array}{l}\text { Powder } \\
\text { composition }\end{array}$} & \multirow{2}{*}{$\begin{array}{l}\text { Phase } \\
\text { composition }\end{array}$} & \multicolumn{2}{|c|}{ Lattice options, § } & \multirow{2}{*}{$\begin{array}{l}\text { CSR, } \\
\mathrm{nm}\end{array}$} & \multirow[t]{2}{*}{$\mathrm{c} / \mathrm{a}$} & \multirow[t]{2}{*}{$V_{\text {cell }}, \AA^{3}$} \\
\hline & & A & $\mathrm{C}$ & & & \\
\hline $\begin{array}{c}3 \mathrm{YSZ}+0 \% \\
\mathrm{HfO}_{2}\end{array}$ & $100 \% \mathrm{~T}$ & 5.0963 & 5.1681 & 31.5 & 1.014 & 134.22 \\
\hline $\begin{array}{c}3 \mathrm{YSZ}+1 \% \\
\mathrm{HfO}_{2}\end{array}$ & $99 \% \mathrm{~T}+1 \% \mathrm{M}$ & 5.0973 & 5.1689 & 31.5 & 1.014 & 134.30 \\
\hline $\begin{array}{c}3 \mathrm{YSZ}+5 \% \\
\mathrm{HfO}_{2}\end{array}$ & $99 \% \mathrm{~T}+1 \% \mathrm{M}$ & 5.0973 & 5.1689 & 31.5 & 1.014 & 134.30 \\
\hline $\begin{array}{c}3 \mathrm{YSZ}+10 \% \\
\mathrm{HfO}_{2}\end{array}$ & $96 \% \mathrm{~T}+4 \% \mathrm{M}$ & 5.0944 & 5.1712 & 31.5 & 1.016 & 134.20 \\
\hline $\begin{array}{c}3 \mathrm{YSZ}+15 \% \\
\mathrm{HfO}_{2}\end{array}$ & $\begin{array}{l}89 \% \mathrm{~T}+11 \% \\
\mathrm{M}\end{array}$ & 5.0912 & 5.1719 & 31.5 & 1.016 & 134.06 \\
\hline
\end{tabular}

Note: $\Delta c=\Delta a= \pm 0,0021 \AA$, T, M are the tetragonal and monoclinic modifications of the $\mathrm{ZrO}_{2}$ lattice.

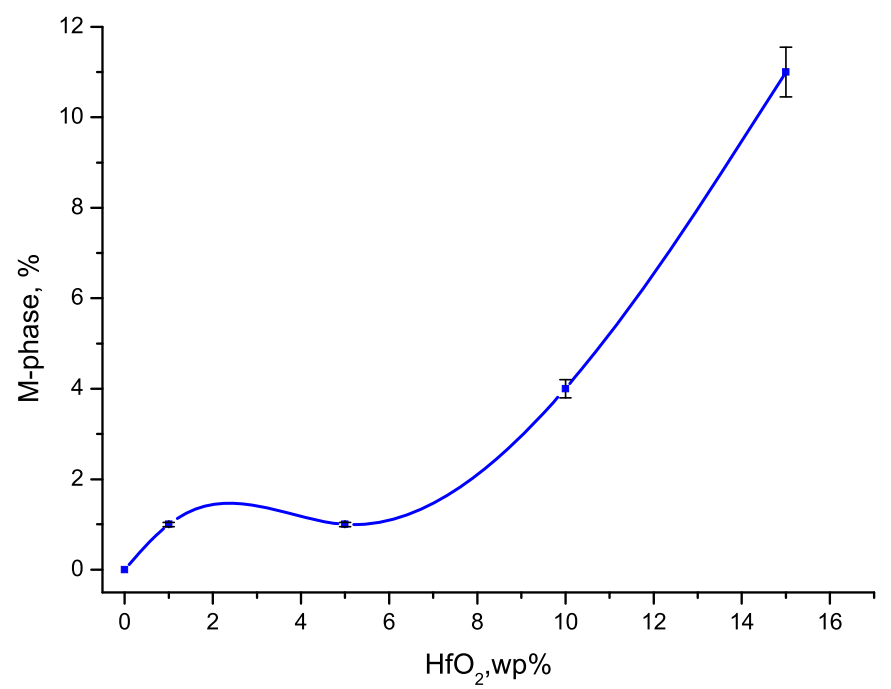

Fig. 4. Dependence of the monoclinic phase amount in $3 \mathrm{YSZ}_{-}-\mathrm{HfO}_{2}$ powders system on the amount of hafnium oxide additive.

n. 8).

A noticeable change in the lattice parameters of the tetragonal phase with large amount addition of hafnium oxide (10 and 15\%), in our opinion, is associated with a strong deformation of the unit cell caused by a "heavy" admixture of hafnium atoms (the atomic weight of hafnium is almost two times the atomic weight of zirconium). In favor of the assumption of the lattice deformation, the facts testify a decrease in the unit cell volume and an increase in its tetragonality level. It should be noted that the CSR size in YSZ with all $\mathrm{HfO}_{2}$ concentrations did not change and amounted to $31.5 \mathrm{~nm}$.

\subsubsection{System $3 \mathrm{YSZ}^{-} \mathrm{HfO}_{2}$. Ceramics}

Fig. 5 shows the diffraction patterns of two-phase zirconiumhafnium ceramics with the composition $3 \mathrm{YSZ}+\mathrm{n} \% \mathrm{HfO}_{2}$, sintered at $1500{ }^{\circ} \mathrm{C}$ for $1 \mathrm{~h}$.

Table 4 shows the phase composition of zirconium - hafnium (3YSZ$\mathrm{HfO}_{2}$ ) ceramics. As can be seen from Table 4, the phase composition of the initial nanopowders (Table 3 ) and ceramics are identical.

Note: $\mathrm{T}$ and $\mathrm{M}$, respectively, are tetragonal and monoclinic modifications of the $\mathrm{ZrO}_{2}$ lattice. The error in the quantitative determination of phases is $\pm 2 \%$.

\subsection{System $3 \mathrm{YSZ}_{-} \mathrm{HfO}_{2}$ Properties}

In Fig. 6 is shown the dependence of the density of $3 \mathrm{YSZ}^{-\mathrm{HfO}_{2}}$ zirconia ceramics on the concentration of $\mathrm{HfO}_{2}$.

Density curve of $3 \mathrm{YSZ}-\mathrm{HfO}_{2}$ ceramics on the concentration of $\mathrm{HfO}_{2}$ correlates with a similar dependence on the amount of monoclinic phase in powders and ceramics (Fig. 4). Both curves show a sharp increase after $5 \%$ of $\mathrm{HfO}_{2}$ concentration. It can be assumed that the observed compaction of ceramics is associated with the presence of a more "heavy" impurity in its composition (as was indicated earlier).

The results of measuring the modulus of normal elasticity (Young's modulus) and the strength of zirconium-hafnium ceramics are shown in Fig. 7.

The behavior of the curves in Fig. $7 \mathrm{a}$ and $\mathrm{b}$ has a similar extreme character. Expressed by an extremum at the $\mathrm{HfO}_{2}$ concentration value of $=5 \%$ indicates the presence of two oppositely directed processes that control the formation of the ceramic structure which appear at different concentrations of the dopant. On the one hand, an increase in the concentration of denser hafnium oxide in a solid solution leads to an increase in the level of physical properties of ceramics in the region to the left of the extremum (Fig. 7). On the other hand, as noted earlier, an increase in the amount of $\mathrm{HfO} 2$ impurity leads to an increase in the content of monoclinic polymorphic modification of zirconium oxide in the samples. The structure which has a lower density value and

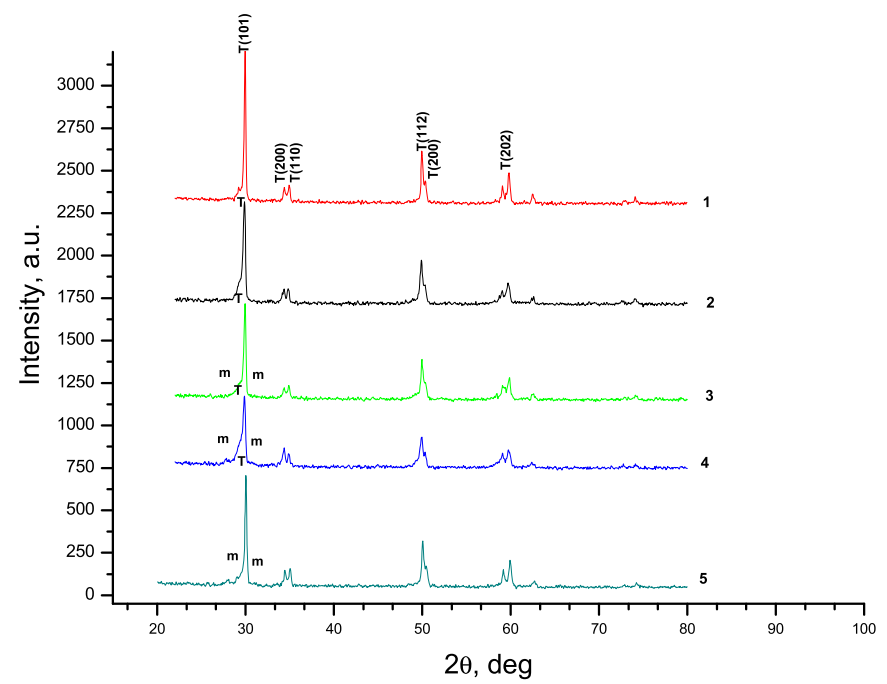

Fig. 5. The diffraction pattern of ceramics with the composition $3 \mathrm{YSZ}+\mathrm{m} \%$ $\mathrm{HfO}_{2}$, where: 1 -3YSZ; 2-3YSZ $+1 \mathrm{HfO}_{2} ; 3-3 \mathrm{YSZ}+5 \mathrm{HfO}_{2} ; 4-3 \mathrm{YSZ}+10 \mathrm{HfO}_{2} ; 5$ $3 \mathrm{YSZ}+15 \mathrm{HfO}_{2}$. 
Table 4

The phase composition of the ceramic composition $3 \mathrm{YSZ}+\mathrm{n} \% \mathrm{HfO}_{2}$.

\begin{tabular}{|c|c|c|c|c|c|}
\hline Ceramics & 3YSZ & $3 \mathrm{YSZ}+1 \% \mathrm{HfO}_{2}$ & $3 \mathrm{YSZ}+5 \% \mathrm{HfO}_{2}$ & $3 \mathrm{YSZ}+10 \% \mathrm{HfO}_{2}$ & $3 \mathrm{YSZ}+15 \% \mathrm{HfO}_{2}$ \\
\hline The phase composition $\%$ & $100 \mathrm{~T}$ & $99 \% \mathrm{~T}+1 \% \mathrm{M}$ & $99 \% \mathrm{~T}+1 \% \mathrm{M}$ & $96,5 \% \mathrm{~T}+3,5 \% \mathrm{M}$ & $89,5 \% \mathrm{~T}+10,5 \% \mathrm{M}$ \\
\hline
\end{tabular}

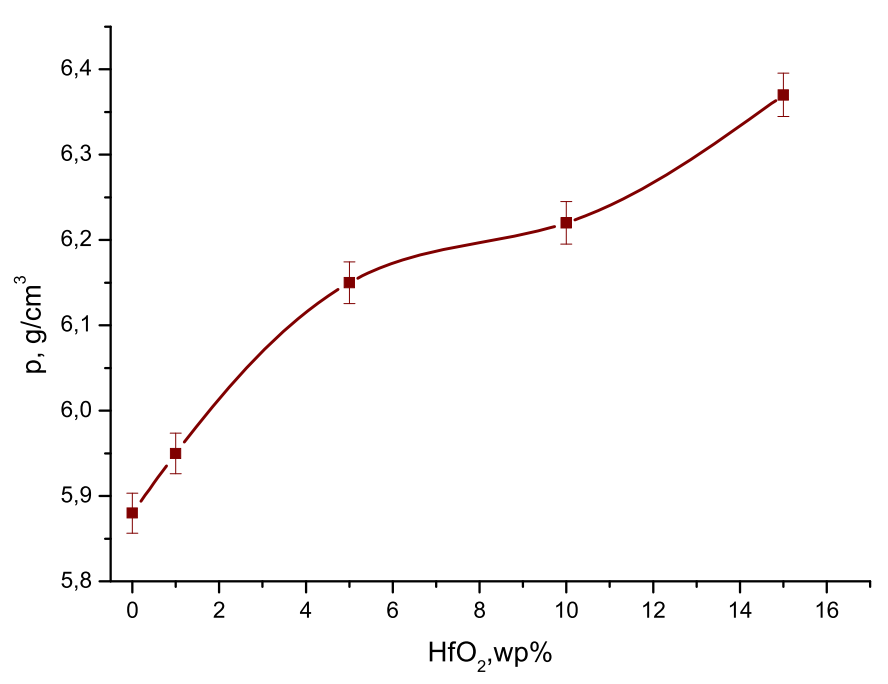

Fig. 6. Dependence of the density of zirconia based ceramic $3 \mathrm{YSZ}-\mathrm{HfO}_{2}$ on the concentration of $\mathrm{HfO}_{2}$.

mechanical properties [11,21] it possibly leads to a deterioration in mechanical characteristics (the area to the right of the extremum, Fig. 5). Thus, the nature of the extremum is most likely due to the features of the crystalline structure of the solid solution (sintering mode $\mathrm{T}$ $=1500{ }^{\circ} \mathrm{C}, 1 \mathrm{~h}$ ).

Fig. 8 shows SEM (scanning electron microscopy) images from the surface of fractures of ceramic samples of compositions $3 \mathrm{YSZ}+1 \% \mathrm{HfO} 2$ (a) and $3 \mathrm{YSZ}+15 \% \mathrm{HfO} 2$ (b), reflecting the microstructure of the samples with maximum concentrations of $\mathrm{HfO}_{2}$ additive.

The nature of fractures of ceramic samples at the maximum and minimum concentrations of hafnium oxide is intercrystalline, which is more preferable than transcrystalline. Fig. 9 shows the surface topology of the samples $3 \mathrm{YSZ}+1 \% \mathrm{HfO}_{2}$ and $3 \mathrm{YSZ}+15 \% \mathrm{HfO}_{2}$ according to SEM.

The grain sizes of the studied ceramic samples were determined by the method of random secants. It was found that the grain size does not change with increase in the concentration of hafnium oxide and it is $0.47-0.53 \mu \mathrm{m}$.

It also should be noted that a tendency toward an increase in the density of ceramics (which is consistent with Fig. 6) and a decrease in the number of pores in them with an increase in the concentration of hafnium oxide.

The qualitative distribution of hafnium and yttrium in the surface of ceramic fractures in $3 \mathrm{YSZ}+15 \% \mathrm{HfO}_{2}$ is shown in Fig. 10 .

In Fig. 10 it can be seen that the distribution of hafnium and yttrium is homogeneous in the zirconia structure over the entire surface of the fractures of the samples. The homogeneous distribution of these elements indicates the synergy of the matrix of zirconium dioxide and the filler in the form of hafnium oxide.

In addition, the absence of $\mathrm{HfO}_{2}$ at the boundaries excludes the possibility of its segregation in the intergranular space with further softening of the material.

\section{Conclusion}

1. Study of the $\mathrm{nY}_{2} \mathrm{O}_{3}-\mathrm{ZrO}_{2}-\mathrm{mHfO}_{2}$ system in the range of hafnium concentrations from 1 to $15 \mathrm{wt} \%$ and yttrium oxide concentration from 0 to $12 \mathrm{~mol} \%$ showed that despite the widespread opinion about the full analogy of yttrium and hafnium oxides it is not complete. The different combination of these oxides changes its initial structure and mechanical properties which can be used to further improving of properties and to vary them due to the scientifical goals. .

2. It was found that the highest mechanical properties have the singlephased $0 \mathrm{Y}_{2} \mathrm{O}_{3}-\mathrm{HfO}_{2}$ and $3 \mathrm{Y}_{2} \mathrm{O}_{3}-\mathrm{HfO}_{2}$ solid solutions, which have a monoclinic crystalline structure with a specific density of $9.85 \mathrm{~g} /$ $\mathrm{cm}^{3}$, hardness $\mathrm{HV}=1130$ and porosity $\varepsilon=0.3 \%$. The minimal values of mechanical characteristics have the two-phased (monoclinic + cubic) samples $6 \mathrm{Y}_{2} \mathrm{O}_{3}-\mathrm{HfO}_{2}$ with a ratio of $\mathrm{M}$ and $\mathrm{C}$ phases 1: 1 .

3. It was shown that the density of three-component $\mathrm{YSZ}$ - $\mathrm{HfO}_{2}$ - ceramics increases in the entire range of hafnium concentrations and an extremum corresponding to a $5 \mathrm{wt} \%$ concentration of $\mathrm{HfO}_{2}$ is observed in the concentration dependences of the strength and Young's modulus.

4. It was shown that in a two-phased $(\mathrm{T}+\mathrm{M}) \mathrm{YSZ}-\mathrm{HfO}_{2}$ ceramics, the amount of monoclinic zirconia increases with an increasing of the amount of hafnium oxide, since there is a typical relationship between the amount of monoclinic $\mathrm{ZrO}_{2}$ and the mechanical characteristics of ceramics.

5. It was found that fractures of $\mathrm{YSZ}-\mathrm{HfO}_{2}$ - ceramics at $\mathrm{HfO}_{2}$ concentrations in the range of $1-15 \%$ have an intercrystallite character.

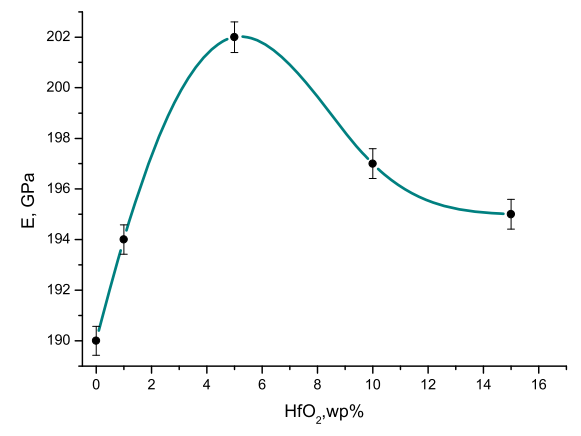

a

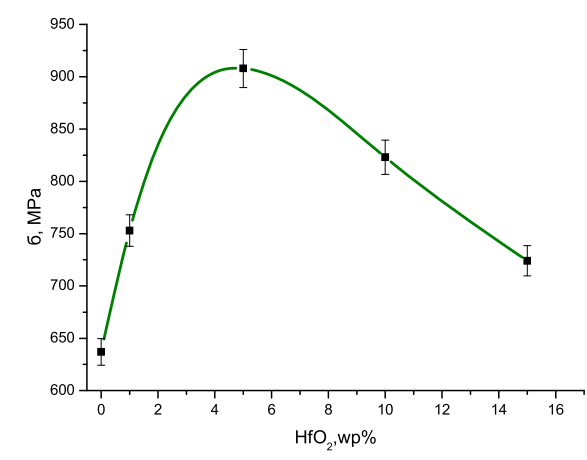

b

Fig. 7. Change in the mechanical characteristics of $3 \mathrm{YSZ}_{-} \mathrm{HfO}_{2}$ ceramics with increase in the concentration of $\mathrm{HfO} \mathrm{O}_{2}$ - Young's modulus (a) and strength (b). 


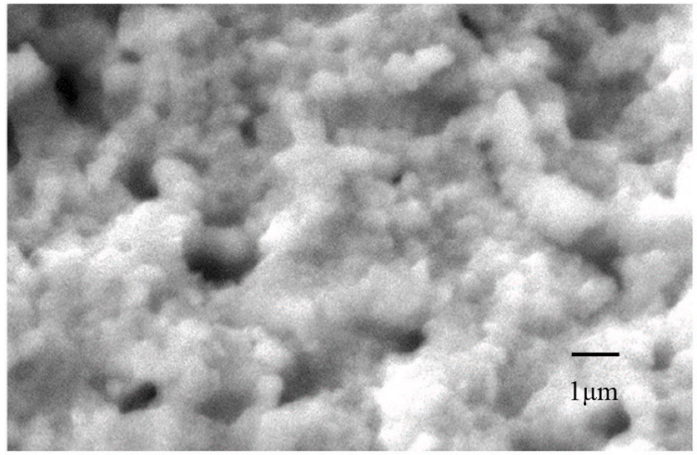

a

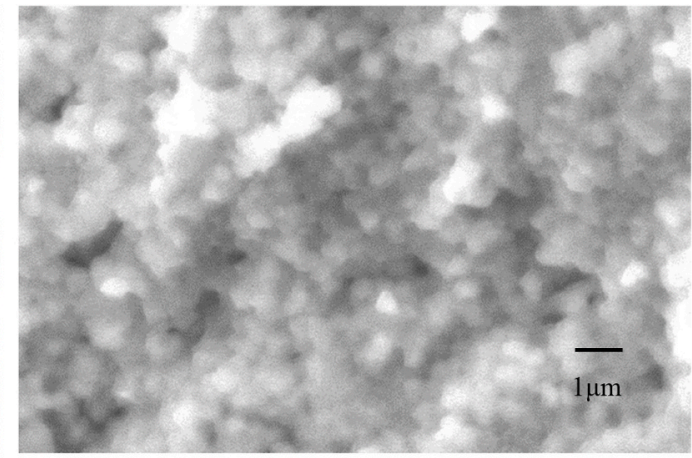

6

Fig. 8. SEM images of ceramic samples $3 \mathrm{YSZ}+1 \% \mathrm{HfO}_{2}$ (a) and $3 \mathrm{YSZ}+15 \% \mathrm{HfO}_{2}$ (b).

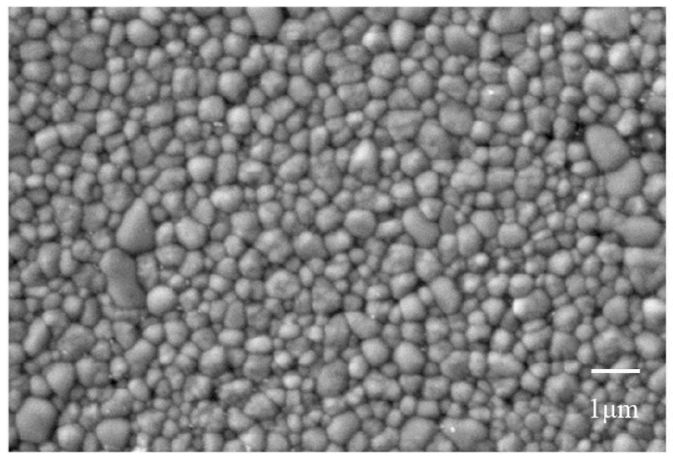

a

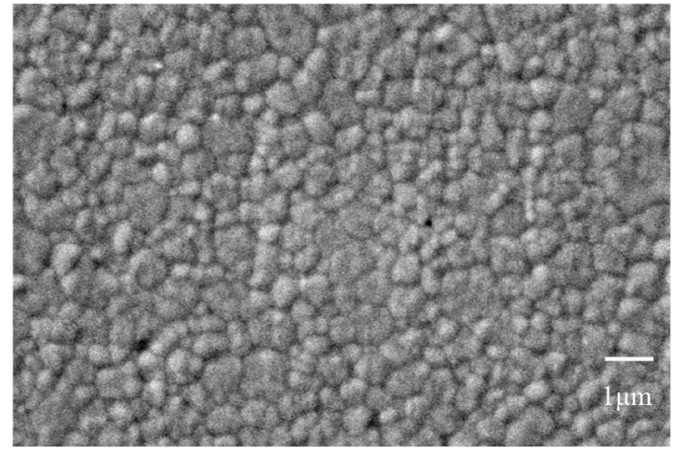

6

Fig. 9. SEM - surface image of samples of $3 \mathrm{YSZ}+1 \% \mathrm{HfO}_{2}$ (a), $3 \mathrm{YSZ}+15 \% \mathrm{HfO}_{2}$ (b).

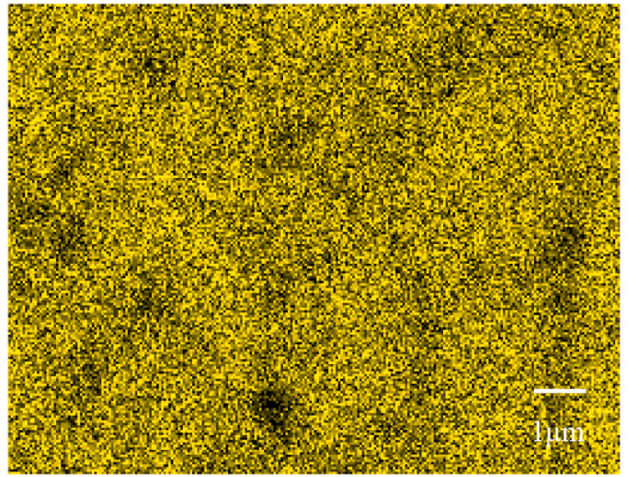

$\mathrm{Hf}$ Wa1

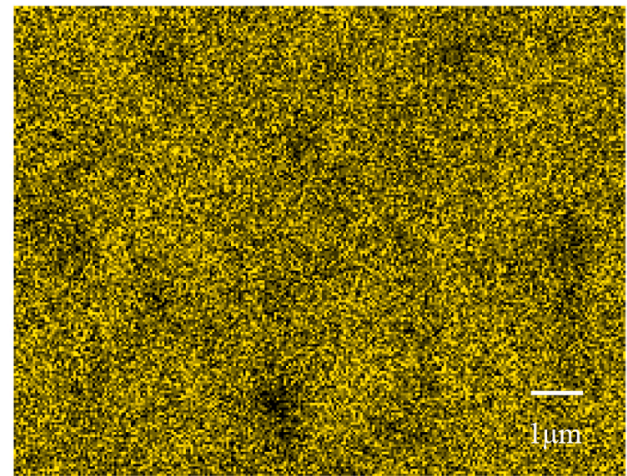

Y La1

a)

б)

Fig. 10. Qualitative distribution of hafnium and yttrium in the fracture surface of $3 \mathrm{YSZ}+15 \% \mathrm{HfO}_{2}$ ceramics distribution of $\mathrm{Hf}$ (a) and distribution of $\mathrm{Y}$ (b).

The homogeneous distribution of yttrium and hafnium impurities over the entire fracture surface was established and the absence of hafnium and yttrium along the grain boundaries was shown which prevents material softening.

The study was performed in the scope of the H2020/MSCA/RISE/ SSHARE number 871284 project and RO-JINR Projects $\mathcal{N} \circ .267 / 2020$ item 25 and $\mathcal{N}$ ㅇ 268/2020 item 51 and $\mathcal{N}$ ‥268/2020 item 57; Poland-JINR Project $\mathcal{N} \circ 75 / 2020$ item 31 .

\section{Declaration of competing interest}

The authors declare that they have no known competing financial interests or personal relationships that could have appeared to influence the work reported in this paper.

\section{References}

[1] Cijun Shuai, Guofeng Liu, Youwen Yang, Fangwei Qi, Shuping Peng, Wenjing Yang, Chongxian He, Guoyong Wang, Guowen Qian A strawberry-like Ag-decorated 
barium titanate enhances piezoelectric and antibacterial activities of polymer scaffold, Nano Energy 74 (2020).

[2] Youwen Yang, Jun Zan, Yang Wenjing Qi Fangwei He Chongxian, Shuhui Huang, Shuping Peng, Cijun Shuai, Metal organic framework as compatible reinforcement in biopolymer bone scaffold, Mat. Chem. Front. (2020) 973-984.

[3] A. Mescherskikh, A. Kuzmin, V. Gorelov, S. Plaksin, Solid electrolytes HfO2-Sc2O3 in the range of compositions with maximum conductivity, Proc. Kola Sci. Centre RAS. 31 (2015) 413-417.

[4] D. Andreev, V. Anikanov, N. Makarov, Ceramics in the $\mathrm{ZrO} 2\left(\mathrm{Y}_{2} \mathrm{O}_{3}\right)-\mathrm{CEO} 2$ $\left(\mathrm{Sm}_{2} \mathrm{O}_{3}\right)$ system for solid-state oxide fuel cells, Adv. Chem. Chemical Technol. 145 (2013) 15-19.

[5] N. Savchenko, T. Sablina, S. Kulkov, Features of the tribological behavior of zirconia-based ceramics under high-speed friction, Bull. Samara SCientific Center Russ. Academy Sci. 4-3 (2011) 857-862.

[6] N. Savchenko, K. Pyatova, S. Kulkov, Friction and wear of ceramics based on ZrO2 $\mathrm{Y}_{2} \mathrm{O}_{3}$ in conditions of high-speed sliding on steel, Tomsk State University Journal Tom. state un-that. Mathematics and mechanics 1 (2007) 84-88.

[7] O. Devno, V. Okovity, Plasma heat-resistant coatings based on zirconium dioxide with increased heat resistance, Sci. Technol. 1 (2015) 35-39.

[8] N. Martyushev, A. Melnikov, T. Nekrasova, Ion beam processing of a sintered ceramic composite, Volga Scientific Herald 2 (2011) 12-16.

[9] A. Vatali, E. Kontonasaki, P. Kavouras, N. Kantiranis, L. Papadopoulou, K. Paraskevopoulos, P. Koidis, Effect of heat treatment and in vitro aging on the microstructure and mechanical properties of cold isostatic-pressed zirconia ceramics for dental restorations, J. Dent. Mat. 30 (2014) 272-282.

[10] L. Thomé, S. Moll, G. Sattonnay, L. Vincent, F. Garrido, J. Jagielski, Radiation effects in cubic zirconia: a model system for ceramic oxides, J. Nucl. Mater. 389 (2009) 297-302, https://doi.org/10.1016/j.jnucmat.2009.02.013.
[11] D. Belichko, I. Nosolev, I. Danilenko, G. Volkova, Effect of high hydrostatic pressure and temperatures on the elastic properties of ceramics based on $\mathrm{ZrO}_{2}$, FTVD 27 (2017) 118-123.

[12] E. Lyapunova, S. Uvarov, M. Grigoriev, S. Kulkov, O. Naimark, Modification of the mechanical properties of zirconium dioxide ceramics by means of multiwalled carbon nanotubes, Nanosystems: Phys. Chem. Math. 1 (2016) 198-203.

[13] R. Smely, E. Kaneva, A. Oshchepkova, V. Bychinsky, T. Aisueva, A. Shchetnikov, G. Pashkova, I. Yakimov, A. Finkelstein, Determination of the mineral composition of lake bottom sediments by X-ray diffraction and physico-chemical modeling, J. SFU. Chem. 3 (2019) 382-394.

[14] A. Botaki, E. Pozdeeva, Elastic moduli and acoustic properties of cermets based on tungsten monocarbide, News TPU 2 (2007) 106-110.

[15] R. Gost, Polymer composites. Bending test method for flat specimens, 56810, URL, http://docs.cntd.ru/document/1200128337, 2015.

[16] B. Johnson, J.L. Jones, Chapter 2 - Structures, Phase Equilibria, and Properties of HfO2, Publishing Series in Electronic and Optical Materials, 2019, pp. 25-45.

[17] R. Ripan, I. Chetyanu, Inorganic Chemistry. Chemistry of Metals, T2, Mir, 1972 , p. 871.

[18] D. Stacy, D. Wilder, The yttria-hafnia system, J. Am. Ceram. Soc. 58 (2006) 285-288.

[19] E.R. Andrievskaya, Phase equilibria in the refractory oxide systems of zirconia, hafnia and yttria with rare-earth oxides, J. Eur. Ceram. Soc. 28 (2008) 2363-2388.

[20] A. Denton, N. Ashcroft, Phys. Rev., A 43 (1991) 3161.

[21] E. Slamovich, F. Lange, Densification behavior of single-crystal and polycrystalline spherical particles of zirconia, J. Am. Ceram. Soc. 73 (1990) 3368-3375. 